\title{
Extraction Equilibrium and Simple Extractive Spectrophotometric Determination of Gold (I\& III) in Water Using the Ion - Pairing Amiloride Hydrochloride
}

\author{
A.S. Bashammakh (Corresponding author) \& M.S. El-Shahawi \\ Department of Chemistry, Faculty of Science, King Abdulaziz University \\ P.O. Box 80203, Jeddah 21589, Saudi Arabia \\ E-mail: abashammkh@kau.edu.sa
}

\begin{abstract}
The chemical equilibrium of the ternary complex ion associate of the complex anion $\mathrm{AuCl}_{4}^{-}$and the ion - pairing reagent 1- (3, 5-diamino-6-chloropyrazinecarboxyl) guanidine hydrochloride monohydrate, $\mathrm{DPG}^{+} . \mathrm{Cl}^{-}$extracted from aqueous solutions of $\mathrm{pH}$ 5-6 onto 4-methyl pentan-2-one was demonstrated. The extraction constants ( $\mathrm{K}_{\mathrm{ex}}$, $\mathrm{K}_{\mathrm{D}}$ and $\beta$ ) of the chemical equilibrium and the structure of the produced associate were determined. The results have indicated that, the formation of the complex ion associate of the chemical structure $\mathrm{DPG}^{+} . \mathrm{AuCl}_{4}{ }^{-}$and the extraction mechanism does not involve solvation of the ion associate by the amine and/or water molecules in the organic phase. Beer's law was obeyed in the range $0.01-2.5 \mu \mathrm{g} \mathrm{mL} \mathrm{mol}^{-1}$ (III) in the aqueous solution. The method was applied successfully for the analysis of gold (I) after oxidation to gold (III). The method was also applied for the analysis of gold (I\& III) at trace concentrations in industrial wastewater samples. Gold (III) ions at trace level in one liter aqueous solution was concentrated in $10.0 \mathrm{~mL}$ by the developed extraction system so an enrichment factor of 100 was achieved. The time taken for the separation and determination of gold ions was in the range of 3-5 min.
\end{abstract}

Keywords: Chemical equilibria, Speciation of gold (I, III), Ion associate, Wastewater

\section{Introduction}

Gold is one of the most important noble metals due to its wide application in industry and economic activity. Gold occur on the Earth in very low natural contents and its concentration in natural water is extremely low, in the range of $0.05-0.2 \mathrm{ng} \mathrm{mL} \mathrm{mL}^{-1}$. It is well known that gold is one of the most interesting micro amount elements due to its significant role on biology and environment. Thus, simple, sensitive and selective methods for determination of trace gold are of great importance.

Several sophisticated techniques, such as laser induced breakdown spectroscopy, inductively coupled plasma mass spectrometry (ICP -MS), inductively coupled plasma atomic emission spectrometry (ICP-AES), electrochemical, neutron activation analysis, total reflection X-ray fluorescence spectrometry have been applied to the determination of gold (Shoursheinin, 2010, PP. 89 -95; Guanghan, 1992, PP. 51-53; Medved, 2004, PP. 60 - 65; Yu, 2003, PP. 225 -231; Navratilova, 2000, PP. 369-372; Itagaki, 2000, PP. 344-349 and Li, 2006 , PP. 841-844) in various matrices including wastewater. However, some of these methods are less often applied in gold analysis due to the complexity and cost of the required instrumentation (Guanghan, 1992, PP. 51-53; Medved, 2004, PP. 60 - 65; Yu, 2003, PP. 225 -231; Navratilova, 2000, PP. 369-372). Thus, spectrophotometric methods still have the advantages in respect of simplicity and low operating costs.

Recently (Zuotao, 1999, PP. 237-241; Pyrzynska, 2005, PP. 1316-1322; Hu, 2006, PP. 627-630 and Fazli, 2009, PP. 210-212) a wide variety of spectrophotometric methods for the determination of gold have been reported. The ion pairing reagents had widely been applied for the pre concentration and/or determination of noble metal ions (Filatova, 2004, PP. 243-245; El-Shahawi, 2005, PP. 319-326; Hassan, 2005, PP.673- 678; El-Shahawi, 2008, PP.313 - 319). Charged bulky cations e.g. amidine, rhodamine derivatives, basic dyes, 18- crown-6 (18C6) oxonium cation, tetra alkyl ammonium, phosphonium or arsonium halides and tetrazolium salts are often used to form extractable complex ion associates with charged bulky oxoanions or anionic complex species of gold (I), gold (III) and other metal ions as their halides, cyanides and thiocyanates (Haddad, 1988, PP. 23 - 36; Burns, 1992, PP. 213-215; Burns,1992, PP. 131-132; El-Shahawi, 1996, PP. 2037-2043; Biswas, 1996, PP. 804-80; Camagong, 2001, PP. 1725-1728; Farag, 2007, PP. 218-228 and Bashammakh, 2009, PP. 413 - 418). Burns, 1988, PP. 185-187 and Burns, 1996, PP.107-109 and other workers (El-Shahawi, 1997, PP. 85-91; AlDhaheri, 1998, PP. 161-1615 and El-Shahawi, 2007, PP.1494-1499) have used the reagent amiloride mono hydrochloride 
extensively as a selective ion-pairing reagent for the determination of some oxoanions e.g. perchlorate, perrhenate, periodate and tetra chloroaurate $\left(\mathrm{AuCl}_{4}{ }^{-}\right)$in different matrices.

Recent literature survey on the title ion - pairing reagent has revealed no study on the chemical equilibrium of the reagent $\mathrm{DPG}^{+} . \mathrm{Cl}^{-}$with $\mathrm{AuCl}_{4}$. Hence, the main objectives of the present article was focused on:

i. Studying the chemical equilibrium of the reagent $\mathrm{DPG}^{+} . \mathrm{Cl}^{-}$with $\mathrm{AuCl}_{4}^{-}$in an attempt to develop a precise extractive spectrophotometric method for the determination and chemical speciation of gold (I, III) species in wastewater samples.

ii. achieving a better association and a better understanding of the extraction mechanism of the produced ion associate of $\mathrm{DPG}^{+} . \mathrm{Cl}^{-}$with $\mathrm{AuCl}_{4}^{-}$in the organic phase.

\section{Experimental}

\subsection{Chemicals and reagents}

Analytical reagent grade chemicals and solvents (BDH, Poole, UK) were used as received. Potassium aurate $\left[\mathrm{KAuCl}_{4}\right]$ and potassium aurocyanide, $\left[\mathrm{KAu}(\mathrm{CN})_{2}\right]$ (Fluka AG, USA) were used for the preparation of stock solutions of gold (III) and gold (I) ions, respectively. The reagent, $\mathrm{DPG}^{+} \cdot \mathrm{Cl}^{-}$(Merck, India) was used witout purification. A stock solution $\left(0.01 \mathrm{~mol} \mathrm{~L}{ }^{-1}, 100 \mathrm{~mL}\right)$ of the reagent $\mathrm{DPG}^{+} . \mathrm{Cl}^{-}$was prepared by dissolving an accurate weight $(0.302 \mathrm{~g})$ of it in $\mathrm{H}_{2} \mathrm{O}-\mathrm{HCl}(1: 1 \mathrm{v} / \mathrm{v})$. Britton - Robinson (B-R) buffer of $\mathrm{pH} 2.1-11$ was prepared (Vogel, 1966).

\subsection{Apparatus}

A double beam Perkin-Elmer (model Lambda EZ-210, USA) spectrophotometer (190-1100 nm) with $1 \mathrm{~cm}$ (path width) quartz cell was used for recording the electronic spectra and the absorbance of the organic extracts. Infrared (IR) spectra were recorded on a Broker FT-IR (model IFS 66, USA) spectrophotometer. A Perkin-Elmer (Analyst TM 800, USA) flame atomic absorption spectrometer (FAAS) was used for measuring the concentration of gold ions at $242.8 \mathrm{~nm}$ at $0.5 \mathrm{~nm}$ slit width before and after extraction with the organic solvent. De - ionized water was obtained from Milli-Q Plus system (Millipore, Bedford, MA, USA) and the pH were recorded on a $\mathrm{pH}$ meter (Orion EA940, MA, USA) with absolute accuracy limits being defined by NIST.

\subsection{Recommended extraction procedures}

\subsubsection{Determination of the extraction equilibrium constants $\left(\mathrm{K}_{\mathrm{D}}, \beta, \mathrm{K}_{\mathrm{ex}}\right)$}

Aliquot aqueous solutions of gold (III) ions $\left(10 \mathrm{~mL}, 1-10 \mu \mathrm{g} \mathrm{mL}^{-1}\right)$ at $\mathrm{pH} 5-6$ were transferred to separating funnels $(50.0 \mathrm{~mL})$. A $2 \mathrm{~mL}$ of the reagent $\mathrm{DPG}^{+} \mathrm{Cl}^{-}$solution $\left(8.0 \times 10^{-5} \mathrm{~mol} \mathrm{~L}^{-1}\right)$ was added to each gold solution. The solutions were completed with B-R buffer of $\mathrm{pH} 5-6$ to the mark of measuring flasks $(25 \mathrm{~mL})$. Each reaction mixture was mixed well and extracted twice $(2 \times 2.5 \mathrm{~mL})$ with 4-methyl pentan-2-one for $2 \mathrm{~min}$. The two phases were then separated out and the organic extract was collected in a $25 \mathrm{~mL}$ beakers containing anhydrous $\mathrm{Na}_{2} \mathrm{SO}_{4}$ $(1.0 \mathrm{~g})$. The contents were swirled to mix and transferred to volumetric flask $(10 \mathrm{~mL})$. The solid residue was then washed with another $5 \mathrm{~mL}(2 \times 2.5)$ of the solvent and the washings were transferred to the measuring flask. The flask was made up to the mark with the solvent. The absorbance of the organic extract was then measured at 362 $\mathrm{nm}$ against blank. The extraction procedures were also carried out in separate experiments at $\mathrm{pH} 5-6$ of the aqueous solutions. After extraction, the gold (III) remained in the aqueous phase $\left(\mathrm{C}_{\mathrm{a}}\right)$ was determined with FAAS. The amount of gold ions of the parallel aqueous solution containing the same amount of gold (III) ions before $\left(\mathrm{C}_{\mathrm{b}}\right)$ extraction was also measured by FAAS. The amount of gold (III) ions extracted in the organic phase was finally calculated by difference $\left(\mathrm{C}_{\mathrm{b}}-\mathrm{C}_{\mathrm{a}}\right)$ between the amount of gold (III) ions before and after extraction. The distribution ratio $\left(\mathrm{D}_{\mathrm{Au}}\right.$ ) of the extraction step was calculated as reported (Burns, 1996, PP. 107-109 and El-Shahawi, 1997, PP. 85-91). Following these procedures, the effect of the diverse ions on the accuracy of the developed method for gold (III) was investigated.

\subsubsection{Determination of gold (I)}

An aliquot portion $(10 \mathrm{~mL})$ of the aqueous solutions containing gold (I) at concentration $<5 \mu \mathrm{g} \mathrm{mL} \mathrm{m}^{-1}$ was transferred to conical flask (50 mL) and oxidized to gold (III) with bromine water after boiling for $5 \mathrm{~min}$ in a closed system (to avoid the evaporation of gold species) and finally cooled to room temperature $\left(25 \pm 1^{\circ} \mathrm{C}\right)$. The gold (III) produced was adjusted to $\mathrm{pH} 5-6$ and completed to the mark with B-R buffer of $\mathrm{pH}$ 5-6. The resulting solution was then analyzed following the recommended procedures for gold (III) determination at $365 \mathrm{~nm}$ versus the reagent blank with the aid of standard curve. 


\subsection{Analytical application}

Industrial wastewater samples $(100 \mathrm{~mL})$ of fertilizer industry from the boundary side of Jeddah city, Saudi Arabia were collected and filtered through a $0.45 \mu \mathrm{m}$ membrane filter. The solution $\mathrm{pH}$ was then adjusted to $\mathrm{pH}$ 5-6 with Britton - Robinson buffer and an accurate amount $(0.5-10.0 \mu \mathrm{g})$ of gold (III) species was added. To the test solution an accurate amount of the reagent $\mathrm{DPG}^{+} . \mathrm{Cl}^{-}\left(2.0 \mathrm{~mL}, 8.0 \times 10^{-5} \mathrm{~mol} \mathrm{~L}^{-1}\right)$ was added to the sample solution and the solution mixture was then transferred to $100 \mathrm{~mL}$ separating funnel. The organic extract was separated out and the absorbance was measured at $362 \mathrm{~nm}$ against reagent blank. The concentration of gold (III) in the organic and aqueous phases was also determined with FAAS.

\section{Results and discussion}

\subsection{Extraction equilibrium}

On mixing the complex anion $\mathrm{AuCl}_{4}^{-}$with the reagent $\mathrm{DPG}^{+} . \mathrm{Cl}^{-}$in aqueous solutions of $\mathrm{pH}$ 5-6 containing sodium chloride $(10 \% \mathrm{~m} / \mathrm{v})$ and shaking with the solvent 4-methyl pentan-2-one for about $2 \mathrm{~min}$, a yellow colored complex ion associate was developed in the organic phase. The electronic spectrum of the organic extract in 4-methyl pentan-2-one showed one well defined peak maximum at $362 \mathrm{~nm}$. Thus, the absorbance of the organic extract of $\mathrm{AuCl}_{4}^{-}$and $\mathrm{DPG}^{+} . \mathrm{Cl}^{-}$was measured at $362 \mathrm{~nm}$ against reagent blank. Assuming no dimerization of the extracted species, the formation of polynuclear complex species is negligible (Alexandrov,1997, PP. 26-32) and the complex anion $\mathrm{AuCl}_{4}^{--}$(aq) is only predominant at the given $\mathrm{pH}$, the overall reaction between the reagent $\mathrm{DPG}^{+} \cdot \mathrm{Cl}^{-}$(aq) and $\mathrm{HAuCl}_{4(\mathrm{aq})}$ is most likely proceeded as follows (Kamburova,1992, PP. $997-1001$ and Hiraoka, 1982, PP. 243-245) :

I. Formation of a ternary complex ion associate in the aqueous phase as follows:

$$
\mathrm{HAuCl}_{4(\mathrm{aq})}+\mathrm{DPG}^{+} \cdot \mathrm{Cl}_{(\mathrm{aq})}^{-} \rightleftharpoons\left[\mathrm{AuCl}_{4}^{-} \cdot \mathrm{DPG}^{+}\right]_{(\mathrm{org})}+\mathrm{HCl}_{(\mathrm{aq})}
$$

The corresponding equilibrium constant, $\beta$ is given by the equation:

$$
\beta=\left[\mathrm{DPG}^{+} . \mathrm{AuCl}_{4}^{-}\right]_{(\mathrm{org})} /\left[\mathrm{AuCl}_{4}^{-}\right]_{\text {(aq) }} \quad\left[\mathrm{DPG}^{+}\right]_{(\mathrm{aq})}
$$

II. Distribution of the complex ion associate between the aqueous and organic phases:

$$
\left[\mathrm{AuCl}_{4}^{-} \cdot \mathrm{DPG}^{+}\right]_{(\mathrm{aq})} \rightleftharpoons\left[\mathrm{AuCl}_{4}^{-} \cdot \mathrm{DPG}^{+}\right]_{(\mathrm{org})}
$$

with a distribution constant, $\mathrm{K}_{\mathrm{D}}$ which is given by the equation:

$$
\mathrm{K}_{\mathrm{D}}=\left[\mathrm{DPG}^{+} . \mathrm{AuCl}_{4}^{-}\right]_{(\text {org. })} /\left[\mathrm{DPG}^{+} . \mathrm{AuCl}_{4}^{-}\right]_{(\mathrm{aq})}
$$

III. Extraction of the complex anion $\mathrm{AuCl}_{4}^{-}$as follows:

$$
\left[\mathrm{AuCl}_{4}^{-}\right]_{(\mathrm{aq})}+\left[\mathrm{DPG}^{+}\right]_{(\mathrm{aq})} \rightleftharpoons\left[\mathrm{AuCl}_{4}^{-} \cdot \mathrm{DPG}^{+}\right]_{(\mathrm{org})}
$$

The corresponding extraction constant, $\mathrm{K}_{\mathrm{ex}}$ is then given by the equation:

$$
\mathrm{K}_{\mathrm{ex}}=\left[\mathrm{DPG}^{+} \cdot \mathrm{AuCl}_{4}^{-}\right]_{(\mathrm{org} .)} /\left[\mathrm{DPG}^{+}\right]_{(\mathrm{aq})} \cdot\left[\mathrm{AuCl}_{4}^{-}\right]_{(\mathrm{aq})}=\mathrm{K}_{\mathrm{D}} \beta
$$

Assuming the complex species $\mathrm{AuCl}_{4}^{-}{ }_{(\mathrm{aq})}$ is the only predominant species in the aqueous phase at equilibrium at the given $\mathrm{pH}$, the value of the distribution ratio, $\mathrm{D}_{\mathrm{Au}}$ was then determined at constant concentration of $\mathrm{AuCl}_{4}{ }^{-}$and various amounts of the reagent $\mathrm{DPG}^{+} . \mathrm{Cl}^{-}$in the aqueous phase employing the equation (Kamburova, 1992, PP. 997 -1001 and Alexandrov, 1997, PP. 26-32):

$$
\mathrm{D}_{\mathrm{Au}}=\left[\mathrm{DPG} \cdot \mathrm{AuCl}_{4}^{-}\right]_{(\mathrm{org})} /\left[\mathrm{AuCl}_{4}^{-}\right]_{(\mathrm{aq})}+\left[\mathrm{DPG} \cdot \mathrm{AuCl}_{4}^{-}\right]_{(\mathrm{aq})}
$$

At low $\mathrm{DPG}^{+} . \mathrm{Cl}^{-}{ }_{(\mathrm{aq})}$ concentration, the term $\left[\mathrm{DPG}^{+} \cdot \mathrm{AuCl}_{4}^{-}\right]_{(\mathrm{aq})}$ can be neglected and equation (7) takes the form:

$$
\mathrm{D}_{\mathrm{Au}}=\left[\mathrm{DPG}^{+} . \mathrm{AuCl}_{4}^{-}\right]_{(\mathrm{org})} /\left[\mathrm{AuCl}_{4}^{-}\right]_{(\mathrm{aq})}
$$

Substituting equation (8) into equations (2) and (6) and taking the logarithms, equation (9) is obtained:

$$
\log \mathrm{D}_{\mathrm{Au}}=\log \mathrm{K}_{\mathrm{D}}+\log \mathrm{B}+\log \left[\mathrm{DPG}^{+} . \mathrm{Cl}^{-}\right]
$$

The values of $\mathrm{D}_{\mathrm{Au}}$ at the initial concentration of $\mathrm{AuCl}_{4}^{-}\left(1 \times 10^{-6} \mathrm{~mol} \mathrm{~L}^{-1}\right)$ in the aqueous phase (pH5-6) at various concentrations $\left(1.0-40.0 \times 10^{-5} \mathrm{M}\right)$ of the reagent $\mathrm{DPG}^{+} . \mathrm{Cl}^{-}$were then calculated. The plot of $\log \mathrm{D}_{\mathrm{Au}}$ vesus $\log$ $\left[\mathrm{DPG}^{+} . \mathrm{Cl}^{-}\right]$was linear (Figure 1) with a slope of 0.91 confirming the formation of $1: 1$ molar ratio of $\mathrm{DPG}^{+}$and 
$\mathrm{AuCl}_{4}{ }_{4}^{-}$in the formation of ternary complex ion associate $\mathrm{DPG}^{+} . \mathrm{AuCl}_{4}{ }^{-}$. The data also have the existence of $\mathrm{AuCl}_{4}{ }_{4}^{-}$species in the organic solvent and the absence of non-specific interaction between the ion associate and the reagent $\mathrm{DPG}^{+} . \mathrm{Cl}^{-}$and also between the bulky anion $\left[\mathrm{AuCl}_{4}\right]_{(\mathrm{aq})}^{-}$and the organic solvent (Hiraoka, 1982, PP.243-245; Alguacil, 1996, PP. 197-208 and El- Shahawi, 1997 PP85 -91). At high concentration of the reagent $\mathrm{DPG}^{+} \cdot \mathrm{Cl}^{-}$, the respective term $\left[\mathrm{AuCl}_{4}^{-}\right]_{(\mathrm{aq})}$ is negligible and equation (7) takes the following form:

$$
\mathrm{D}_{\mathrm{Au}}=\left[\mathrm{DPG}^{+} . \mathrm{AuCl}_{4}^{-}\right]_{(\text {org. })} /\left[\mathrm{DPG}^{+} . \mathrm{AuCl}_{4}^{-}\right]_{(\mathrm{aq})}=\mathrm{K}_{\mathrm{D}}
$$

Thus, at high $\mathrm{DPG}^{+} . \mathrm{Cl}^{-}$concentration, the plot of the experimental data in the same coordinates of equation (9) has yielded a straight line slightly parallel to the abscissa with negative slope of -0.04 close to zero (Figure 1) confirming, the proposed chemical model, the proposed ternary complex ion associate, the absence of non-specific interaction between the produced complex associate and the reagent and also between the bulky anion $\left[\mathrm{AuCl}_{4}\right]_{(\text {(aq) }}^{-}$and the organic solvent (Hiraoka, 1982, PP. 243-245 and Alguacil, 1996, PP.197-208). The data have also confirmed the non - specific interaction between the extracted species $\mathrm{DPG}^{+} . \mathrm{AuCl}_{4}{ }^{-}$and the solvent (Hiraoka, 1982, PP. 243-245 and Alguacil, 1996, PP.197-208). The values of the equilibrium constants (B and $\left.\mathrm{K}_{\mathrm{D}}\right)$ and the extraction constant, $\left(\mathrm{K}_{\mathrm{ex}}=\beta \times \mathrm{K}_{\mathrm{D}}\right)$ of the formed ion associate computed from the linear plot (Figure 1) are: $\beta=2.07 \pm 0.2 \times 10^{4}, K_{D}=11.97 \pm 0.7, K_{e x}=2.0 \pm 0.3 \times 10^{3}$. Using these constants, the theoretical correlation of $\mathrm{D}_{\mathrm{Au}}$ as a function of $\mathrm{DPG}^{+} . \mathrm{Cl}^{-}$was calculated. The results revealed satisfactory agreement between the experimental and the theoretical data confirming the molar ratio $(1: 1)$ of the reagent $\mathrm{DPG}^{+} . \mathrm{Cl}^{-}$to the complex anion $\mathrm{AuCl}_{4}{ }^{-}$in the extracted complex ion associate $\mathrm{DPG}^{+}$. $\mathrm{AuCl}_{4}{ }^{-}$.The computed values of the extraction constants $\beta, K_{D}$ and $K_{e x}$ are better than the data reported (Patel, 1986,PP. 1547 -1551) using amidine ion pair. The developed extraction procedures also offered lower reaction time, much less toxic option and low cost for the separation and/or determination of gold (III) species.

\subsection{Extraction mechanism}

Assuming an overall gold (III) extraction in which the reagent amiloride abbreviated by $\mathrm{RNH}_{2}$ has the general equilibrium equation:

$$
\begin{aligned}
& \mathrm{RNH}_{2(\mathrm{aq})}+\mathrm{H}^{+}{ }_{(\mathrm{aq})}+\mathrm{AuCl}_{4}^{-}{ }_{(\mathrm{aq})} \rightleftharpoons \mathrm{RNH}_{3}^{+} \cdot \mathrm{AuCl}_{4}^{-} \text {(org) } \\
& \mathrm{K}_{\mathrm{ex}}=\left[\mathrm{RNH}_{3}{ }^{+} \cdot \mathrm{AuCl}_{4}^{-}\right]_{(\mathrm{org})} /\left[\mathrm{AuCl}_{4}^{-}\right]_{(\mathrm{aq})}\left[\mathrm{H}^{+}\right]_{(\mathrm{aq})}\left[\mathrm{RNH}_{2}\right]_{(\mathrm{aq})}
\end{aligned}
$$

On substituting equation (1) onto equation (10) equation (13) was obtained:

$$
\mathrm{K}_{\mathrm{ex}}=\mathrm{D}_{\mathrm{Au}} /\left[\mathrm{H}^{+}\right]_{(\mathrm{aq})} \cdot\left[\mathrm{RNH}_{2}\right]_{(\mathrm{aq})}
$$

Taking logarithms and rearranging the equation, the following equation :

$$
\log \mathrm{D}_{\mathrm{Au}}=\log \mathrm{K}_{\mathrm{ext}}-\mathrm{pH}+\log \left[\mathrm{RNH}_{2}\right]_{(\mathrm{aq})}
$$

was obtained and the corresponding coefficients for the $\mathrm{pH}$ and the amiloride concentration was achieved. The plot of $\mathrm{pH}$ versus $\log \mathrm{D}_{\mathrm{Au}}$ at constant reagent concentration and the aqueous phase containing $0.25 \mathrm{mmoL}^{-1}$ gold (III) using aqueous/organic phase volume ratio of $1 / 1$ and shaking for 3 min was linear with a slope 0.965 close to unity confirming the value for the $\mathrm{pH}$ coefficient given in equation (14). Based on the work reported earlier (Alguacil, 1996, PP. 197-208) and by definition, when $\mathrm{D}_{\mathrm{Au}}=1$ in a solvent extraction system, the $\mathrm{pH}$ obtained is known as $\mathrm{pH}_{50}$. Thus, on replacing $\mathrm{pH}_{50}$ in equation (11), the following expression was obtained:

$$
\mathrm{pH}_{50}=\log \mathrm{K}_{\text {ext }}+\log \left[\mathrm{RNH}_{2}\right]_{(\mathrm{aq})}
$$

On plotting $\log \mathrm{D}_{\mathrm{Au}}$ versus $\log \left[\mathrm{RNH}_{2}\right]_{\text {(aq) }}$ (Figure 1) a slope of 0.956 was obtained. This value close to unity and corresponds to the value of $\log \left[\mathrm{RNH}_{2}\right]$ coefficient given in equations (13) and (14). Elemental analysis of the produced ternary complex ion associate in the solid form after solvent evaporation: $\left[\mathrm{AuOC}_{6} \mathrm{H}_{9} \mathrm{~N}_{7} \mathrm{Cl}_{5}\right.$ ] required: $12.6 \% \mathrm{C}, 1.57 \% \mathrm{H}, 17.2 \% \mathrm{~N}, 31.1 \% \mathrm{Cl}$ and $34.7 \% \mathrm{Au}$; Found $12.9 \% \mathrm{C}, 1.7 \% \mathrm{H}, 17.7 \% \mathrm{~N}, 31.7 \% \mathrm{Cl}$ and $35.6 \% \mathrm{Au}$. The IR spectra of the reagent $\mathrm{DPG}^{+} \mathrm{Cl}^{-}$and its solid ion complex associate recorded in $\mathrm{KBr}$ disk showed the characteristic frequencies of $v(\mathrm{~N}-\mathrm{H}), v(\mathrm{~N}-\mathrm{N}), v(\mathrm{~N}-\mathrm{H})+(\mathrm{C}-\mathrm{N}), v(\mathrm{~N}-\mathrm{C}-\mathrm{S})$ and $v(\mathrm{Au}-\mathrm{Cl})$ vibrations at 3456 (br.), 1626 (s), 1516 (s) and $450 \mathrm{~cm}^{-1}$ (Nakamoto, 1978, PP. 232 -239), respectively confirming the proposed structure. The results also added further conclusive evidence that, the amiloride reagent extracted gold (III) from the aqueous solution containing $\left[\mathrm{AuCl}_{4}^{-}\right]_{(\mathrm{aq})}$, and the absence of non-specific interaction between the ion associate and the reagent $\mathrm{DPG}^{+} . \mathrm{Cl}^{-}$and also between the bulky anion $\left[\mathrm{AuCl}_{4}\right]_{(\mathrm{aq})}^{-}$and the organic solvent (Hiraoka, 1982, PP.243-245 and Alguacil, 1996, PP. 197-208). Thus, the extraction mechanism of the anion $\mathrm{AuCl}_{4}^{-}$from the aqueous solution at $\mathrm{pH} 5-6$ by the reagent $\mathrm{DPG}^{+} . \mathrm{Cl}^{-}$did not involve solvation of the produced ion associate $\left(\mathrm{DPG}^{+} \mathrm{AuCl}_{4}^{-}\right)$in the organic phase by amine and/or water molecules (Hiraoka, 1982, 
PP.243-245 and Alguacil, 1996, PP. 197-208).

\subsection{Analytical performance}

The plot of the absorbance of the developed ion associate $\mathrm{DPG}^{+} . \mathrm{AuCl}_{4}^{-}$(org) in the organic phase at $362 \mathrm{~nm} v s$. gold (III) concentration (C, $\mu \mathrm{g} \mathrm{mL}{ }^{-1}$ ) was linear confirming Beer's -Lambert law (Marczenko, 1986, PP. 68 - 70 and Miller, 1994, PP.115-125) in the concentration range 0.01 $-2.5 \mu \mathrm{gmL}^{-1}$ gold (III) in the aqueous solution with a correlation coefficient of 0.99 . The molar absorptivity calculated from Beer's-Lambert plot and the Sandell's sensitivity index (Marczenko, 1986, PP. $69-70$ ) of the ion associate were found $2.05 \times 10^{4} \mathrm{~L} \mathrm{~mol}^{-1}$ $\mathrm{cm}^{-1}, 0.069 \mu \mathrm{gcm}^{-2}$, respectively. The effective concentration range of gold (III) as evaluated by Ringbom's plot (Marczenko, 1986, PP. 69 -70) was found equal 1.5-1.5 $\mu \mathrm{g} \mathrm{mL}^{-1}$. A lower limit of detection (LOD) of 0.005 $\mu \mathrm{g}$ $\mathrm{mL}^{-1}$ was achieved using of the formula LOD $=3 S_{y / x} / b$ where, $S_{y / x}$ is the standard deviation of $y$ - residual and $b$ is the slope of the calibration plot (Miller, 1994, PP.115-125). The lower limit of quantification (LOQ $=10 S_{y / x} / b$ ) under the established conditions for gold (III) was $0.033 \mu \mathrm{gmL}^{-1}$. The LOD could be improved to lower value by increasing the sample volume of the aqueous phase containing ultra trace concentration of gold and amiloride at the optimum experimental conditions and shaking with the organic solvent. A relative standard deviation (RSD) of $2.96 \%$ ( $\mathrm{n}=5$ ) was obtained for gold (III) at concentration $0.5 \mu \mathrm{g} \mathrm{mL}^{-1}$. The figure of merits (LOD, linear range, RSD) of the proposed procedure was compared with many of the reported spectrometric methods and in the literature (Pyrzynska, 2005, PP. 1316-1322; Fazli, 2009, PP. 210-212; Zuotao, 1999, PP. 237-241 and El-Shahawi, 2008, PP. 313 -319). The time consuming on the developed method is comparable with some reported methods (Pyrzynska, 2005, PP. 1316-1322 and Fazli, 2009, PP. 210-212) confirming its precision.

\subsection{Interference studies}

The selectivity of the developed method for the determination of gold (III) at $1.0 \mu \mathrm{gmL}^{-1}$ was tested in the presence of a relatively high excess $\left(0.1-1 \mathrm{mg} \mathrm{mL}^{-1}\right)$ of some diverse ions which are often accompanying gold in water. The tolerance limit was defined as the concentration of the diverse ion added causing a relative error in the absorbance at $362 \mathrm{~nm}$ in the range $\pm 3 \%$. A recovery percentage of $100 \pm 2.5 \%$ gold (III) and a standard deviation of \pm 0.12 were achieved in the presence of the ions: $\mathrm{Li}^{+}, \mathrm{Na}^{+}, \mathrm{K}^{+}, \mathrm{Ca}^{2+}, \mathrm{NH}_{4}^{+}, \mathrm{Al}^{3+}, \mathrm{Fe}^{2+}, \mathrm{Fe}^{3+}, \mathrm{Ni}^{2+}, \mathrm{Co}^{2+}$, $\mathrm{Pd}^{2+}, \mathrm{Pt}^{2+}, \mathrm{Cu}^{2+}, \mathrm{Zn}^{2+}$ and $\mathrm{Ag}^{+}$at 1:100 tolerable concentration of gold(III) to the diverse ions, respectively. The ions $\mathrm{Fe}^{3+}, \mathrm{MnO}_{4}^{-}, \mathrm{VO}_{3}{ }^{-}$and $\mathrm{NO}_{3}{ }^{-}$interfered seriously even at low concentrations. The positive interference of these ions is most likely assigned to the ability of these anions to form relatively stable complex ion associates with the reagent $\mathrm{DPG}^{+}$. $\mathrm{Cl}^{-}$. Interference of $\mathrm{MnO}_{4}{ }^{-}$was eliminated by adding traces of $\mathrm{NaN}_{3}(0.1 \% \mathrm{w} / \mathrm{v})$ while, the influence of the ions $\mathrm{Fe}^{3+}$ and $\mathrm{VO}_{3}^{-}$was minimized successfully by the addition of $\mathrm{NaF}(0.1 \%)$ and promotes unambiguous and sensitive determination of gold (III).

\subsection{Analytical applications}

\subsubsection{Analysis of gold (I) and / or gold (III)}

The values of the extraction constants $\left(\mathrm{K}_{\mathrm{D}}, \beta\right.$ and $\left.\mathrm{K}_{\mathrm{ex}}\right)$ in the present study and the molar absorptivity suggested the application of the developed extraction equilibria for extractive spectrophotometric determination of gold (III) at trace concentrations of gold $\left(0.05-2.0 \mu \mathrm{gmL}^{-1}\right)$. Different amounts of gold (III) were spiked onto distilled water $(100.0 \mathrm{~mL})$ and the solutions were subjected to the pre recommended extraction procedures. A satisfactory recovery percentage in the range $96-98 \pm 3 \%$ was obtained between the amount of gold (III) added and measured confirming the accuracy of the developed procedures. The developed procedure was also applied successfully for the determination of gold (I) species at various concentrations $\left(0.1-2.0 \mu \mathrm{g} \mathrm{mL}^{-1}\right)$ after oxidation to gold (III) with $\mathrm{Br}_{2}$ water in the presence of $\mathrm{HCl}$ as described earlier (El-Shahawi, 2007, PP.1494-1499). A recovery percentage $(98 \pm 3.4 \%, \mathrm{n}=5)$ of gold (I) was also achieved suggesting the use of the method for the analysis of total inorganic gold and chemical speciation of gold (I \& III) species and in aqueous media. Thus, the analysis of the binary mixture of gold (I) and (III) at a total amount $(10-20 \mu \mathrm{g} / 25 \mathrm{~mL}$ aqueous solution) was carried out as follows: an aliquot mixture was first determined according to the described procedure for gold (III). Another aliquot mixture was oxidized to gold (III) with bromine water-HCl (El-Shahawi, 2007, PP.1494-1499) and determined as described in for gold (I) species. Gold (I) ions in the water samples were then determined by the difference $\left(\mathrm{A}_{2}-\mathrm{A}_{1}\right)$ between the absorbance of the aliquots before $\left(\mathrm{A}_{1}\right)$ and after $\left(\mathrm{A}_{2}\right)$ oxidation. The results are summarized in Table 1. A satisfactory recovery percentage in the range $96.6-103.2 \%$ was obtained with good reproducibility. A relative standard deviation in the range of $1.9-2.3$ and $2.1-2.2 \%$ for gold (I) and (III) was also obtained, respectively. The proposed method was compared favorably with FAAS and the dithizone spectrophotometric methods i(Marczenko, 1986, P. 303) for gold (III) determination. The value of the Student's $t$ - test $(\mathrm{t}=2.61$ at $95 \%)$ was found greater than the theoretical one $(t=2.31)$, so there is no significance differences between the two means. 


\subsubsection{Analysis of gold in wastewater}

The extraction procedure was also applied for the separation and subsequent determination of gold (III) by the standard addition of gold (III) species at $5-10 \mu \mathrm{g} \mathrm{mL}^{-1}$ onto industrial wastewater samples. A $100.0 \mathrm{~mL}$ of water samples was filtered, adjusted to the required $\mathrm{pH}$ and extracted as described in the experimental section. The organic extract was analyzed for gold by the developed extractive spectrophotometric method and also by the standard FAAS. The results are given in Table 2. An acceptable recovery percentage of gold (III) in the range of $98-103 \pm 2.42-3.2 \%$ was achieved. The decrease in the recovery percentage at $5.0 \mu \mathrm{g} \mathrm{mL}^{-1}$ gold was improved by increasing the shaking time of the aqueous test solution with the ion pair reagent to $3-4 \mathrm{~min}$. The $\mathrm{t}$ - and Ftests at $95 \%$ confidence levels did not exceed the tabulated (theoretical) ones and revealed no significant differences (Table 2) between the averages and the variances of the developed and the standard FAAS methods. At $95 \%$ confidence, the calculated value of $t=2.43$ is greater than the theoretical one $(t=2.31)$ so there is a difference between the two means.

\section{Conclusion}

The reaction of the reagent $\mathrm{DPG}^{+} . \mathrm{Cl}^{-}$with $\mathrm{AuCl}_{4}{ }^{-}$is rapid (the time taken for the separation and determination of gold ions is at most 3-5 min) and does not involve any stringent conditions. The values of $\mathrm{K}_{\mathrm{D}} \beta$, and $\mathrm{K}_{\mathrm{ex}}$, of the produced associate $\mathrm{DPG}^{+} . \mathrm{AuCl}_{4}^{-}$compete favorably with the most ion pair reagents (El-Shahawi, 1996, PP. 2037-2043 and Patel, 1986 and PP. 1547.-1551) and allowed the use of the system for photometric determination of gold (III). Gold (III) ions at trace or ultra trace in one liter aqueous solution was concentrated in $10.0 \mathrm{~mL}$ by the developed system so an enrichment factor of 100 was achieved. The extraction system is also suitable for the chemical speciation of gold (I, III) ions.

\section{References}

AlDhaheri, S.M. (1998). Chemical equilibria of the complex ion associate of periodate and the ion pairing reagent 1- (3, 5-diamino-6-chloropyrazinecarboxyl) guanidine hydrochloride monohydrate. Talanta, 46, 161-1615.

Alexandrov, A., Budevsky, O., Dimitrov, A. (1997). Investigation of the extraction equilibrium of ternary ion association complex of thallium (III) with iodo-nitro-tetrazolium chloride. Journal of Radioanaytical Chemistry, 29, 26-32.

Alguacil, F.J., Caravaca, C. (1996). Synergistic extraction of gold (I) cyanide with the primary amine primene-Jmt and the phosphine oxide cyanex 921. Hydrometallurgy, 42, 197-208.

Bashammakh, A.S., Bahaffi, S.O., Al-Shareef, F.M., El-Shahawi, M.S. (2009). Development of an analytical method for trace gold in aqueous solution using polyurethane form sorbents: kinetic and thermodynamic characteristic of gold (III) sorption. Anal Sci, (Japan), 25, 413 - 418.

Biswas, S., Mondal, H.K., Basu, S. (1996). Determination of gold by adogen-464 extraction. Indian J. Chem., 35A, 804-805.

Burns, D.T, Barakat, S.A., Harriott, M., El-Shahawi, M.S. (1992). Flow injection extraction spectrophotometric determination of manganese (VII) with benzyl tributylammonium permanganate. Anal. Chim. Acta, 270, 213-215.

Burns, D.T., Barakat, S.A., El-Shahawi, M.S., Hariott, M. (1992).Flow-injection extraction spectrophotometric determination of permanganate with triphenylsulphonim cations. Fresenius J. Anal. Chem., 344, 131-132.

Burns, D.T., El-Shahawi, M.S., Kerrigan, M.J., Smyth, P.M.T. (1996). Spectrophotometric determination of rhenium as perrhenate by extraction with amiloride hydrochloride. Anal. Chim. Acta, 322, 107-109.

Burns, D.T., Hanprasopwattana, P. (1988). Extractive spectrophotometic determination of perchlorate using the ion pair amiloride monohydrochloride. Anal. Chim. Acta, 118, 185-187.

Camagong, C.T., Honjo, T. (2001). Separation of gold (III) as its ion -pair complex with 18-crown-6 from hydrochloric acid media by means of solvent extraction. Anal. Sci.(Japan), 17, 1725-1728.

El-Shahawi, M.S, Al-Hashimi, F.A. (1996). Spectrophotometric determination of periodate or iodate and ions by liquid-liquid extraction as an ion-pair with tetramethylammonium iodide. Talanta, 43, 2037-2043.

El-Shahawi, M.S, Hassan, S.S.M., Othman, A.M, .El-Sonbati, M.A. (2008). Retention profile and saubsequent chemical speciation of chromium (III) and (VI)) in industrial wastewater samples employing some onium cations loaded polyurethane foams. Microchemical Journal, 89, 313 -319.

El-Shahawi, M.S. (1997). Extraction equilibrium of the ion-associate of periodate with amiloride hydrochloride 
and simultaneous spectrophotometric determination of periodate and iodate ions by liquid-liquid extraction. Anal. Chim. Acta, 356, 85-91.

El-Shahawi, M.S., Bashammakh, A.S., Bahaffi, S.O. (2007). Chemical speciation and recovery of gold (I \& III) from wastewater and silver by liquid-liquid extraction with the ion pair reagent amiloride mono hydrochloride and AAS determination. Talanta, 72, 1494-1499.

El-Shahawi, M.S., Hassan, S.S.M., Othman, A.M., Zyada, M.A., El-Sonbati, M.A. (2005). Chemical speciation of chromium (III\&VI) employing extractive spectrophotometry and tetraphenylarsonium chloride or tetraphenylphosphonium bromidesss as an ion-pair reagent. Anal. Chim. Acta, 534, 319-326.

Farag, A.B., Soliman, M.H., Abdel-Rasoul, O.S., El-Shahawi M.S. (2007). Sorption characteristics and chromatographic separation of gold (I\& III) from silver and base metal ions using polyurethane foams. Anal. Chim. Acta, 601, 218-228.

Fazli, Y., Hassan, J., Karbasi, M.H., Sarkouhi M. (2009). A Simple spectrophotometric method for determination of gold (III) in aqueous samples. Minerals Engineering, 22, 210-212.

Filatova, D.G., Ryazanova, L.N., Shiryaeva, O.A., Zorov, N.B., Kaprov, Y. (2004). Atomic absorption determination of gold as complex ammines. J. Anal. Chem., 59, 243-245.

Guanghan, L., Jinya, X. (1992). Determination of trace amounts of gold in wastewater by graphite furnace atomic-absorption spectrophotometry with preconcentration on trioctylphosphine oxide chemically modified tungsten wire matrix. Talanta, 39, 51-53.

Haddad, P.R., Rochester, N.E. (1988). Ion - interaction reversed - phase chromatographic method for the determination of gold (I) cyanide in mine process liquors using automated sample preconcentration, $J$. Chromatogr, 439, 23 - 36.

Hassan, S.S.M., El-Shahawi, M.S., Othman, A.M., Mosaad, M.A. (2005). A potentiometric rhodamine-B based membrane sensor for the selective determination of chromium ions in wastewater. Anal. Sci. (Japan), 21, 673-678.

Hiraoka, M. (1982). Crown compounds, their characteristics and applications, El-Sevier, Tokyo, 243-245.

Hu, Q., Chen, X., Yang, X., Huang, Z., Chen, J., Yang, G. (2006). Solid phase extraction and spectrophotometric determination of Au (III) with 5-(2-hydroxy-5-nitrophenylazo) thiorhodamine. Anal. Sci (Japan), 22, 627-630.

Itagaki, T., Ashino, T., Takada, K. (2000). Determination of trace amounts of gold and silver in high-purity iron and steel by electrothermal atomic absorption spectrometry after reductive co precipitation. Fresenius J. Anal. Chem., 368, 344-349.

Kamburova, S.M. (1992). A highly sensitive spectrophotometric method for the determination of iodate using leuco xylene cyanol FF. Talanta, 39, $997-1001$.

Li, J.F., Bai, L.F, Wang, Y.H., Wang, H.Y. (2006). Rapid determination of gold in geological samples using flow injection solid phase chemiluminescences. Anal. Sci (Japan), 22: 841-844.

Medved, J., Bujdos, M., Matus, P., Kubova, J. (2004). Determination of trace amounts of gold in acid-attacked environmental samples by atomic absorption spectrometry with electrothermal atomization after preconcentration. Anal. Bioanal. Chem., 379, 60 - 65.

Marczenko, Z. (1986). Spectrophotometric determination of elements, $3^{\text {rd }}$ edition, Ellis Horwood Chichester, U.K, PP.68 -70, 203.

Marczenko, Z. (1986). Spectrophotometric determination of elements, $3^{\text {rd }}$ edition, Ellis Horwood Chichester, U.K, PP.68 -70, 203.

Miller, J.C., Miller, J.N. (1994). Statistics for analytical chemistry $4^{\text {th }}$ edition, Ellis-Horwood, New York, PP.115-125.

Nakamoto, K. (1978). Infrared and raman spectra of inorganic and coordination compounds, $3^{\text {rd }}$ edition, Wiley: New York.

Navratilova, Z., Kula, P. (2000). Determination of gold using clay modified carbon paste electrode. Fresenius $J$. Anal. Chem., 367, 369-372.

Patel, K.S., Lieser, K.H. (1986). Extraction and spectrophotometric determination of gold (III) by use of amides and amidines. Anal. Chem., 58 (7), 1547 -1551. 
Pyrzynska, K. (2005). Recent development in the determination of gold by atomic spectrometry techniques. Spectrochim. Acta B, 60, 1316-1322.

Shoursheinin, F., Sajad, B., Parvin, P. (2010). Determination of gold fineness by laser induced breakdown spectroscopy with the simultaneous use of $\mathrm{CW}-\mathrm{CO}_{2}$ and Q-SW Nd: YAG lasers. Optics and Lasers in Engineering, 48, 89 -95.

Vogel, A.I. (1966). A Text Book of Quantitative Inorganic Analysis" $3^{\text {rd }}$ edn., Longmans Group Ltd., England.

Yu, M., Suna, D., Huangb, R., Tian, W., Shen, W., Zhang, H., Xua, N. (2003). Determination of ultra-trace gold in natural water by graphite furnace atomic absorption spectrometry after in situ enrichment with thiol-cotton fiber. Anal.Chim.Acta, 479, 225 -231.

Zuotao, Z., Creedy, T.M., Townshend, A. (1999). Flow injection spectrophotometric determination of gold using 5-(4-sulphophenylazo)-8-aminoquinoline, Anal. Chim. Acta, 401, 237-241.

Table 1. Analytical data of gold (I) and gold (III) in their binary mixtures in aqueous media $(10 \mathrm{~mL})$ by the proposed extractive spectrophotometric method

\begin{tabular}{|c|c|c|c|c|c|}
\hline \multicolumn{4}{|c|}{ Gold species, } & \multicolumn{2}{|c|}{ Recovery, \%* } \\
\hline \multicolumn{2}{|c|}{ Taken, $\mu \mathrm{g}$} & \multicolumn{2}{|c|}{ Found, $\mu \mathrm{g}$} & & \\
\hline $\mathrm{Au}^{+}$ & $\mathrm{Au}^{3+}$ & $\mathrm{Au}^{+}$ & $\mathrm{Au}^{3+}$ & $\mathrm{Au}^{+}$ & $\mathrm{Au}^{3+}$ \\
\hline 5.0 & 5.0 & 4.8 & 5.1 & $96.0 \pm 2.3$ & $102.0 \pm 2.3$ \\
\hline 10.0 & 10.0 & 9.75 & 10.22 & $97.5 \pm 2.9$ & $102.4 \pm 2.1$ \\
\hline 10.0 & 10.0 & 9.8 & 9.90 & $99.4 \pm 2.7$ & $99.0 \pm 1.9$ \\
\hline
\end{tabular}

* Average $(\mathrm{n}=5) \pm$ relative standard déviation.

Table 2. Results of the extractive spectrophotometric determination of gold (III) spiked $(0.5-10 \mu \mathrm{g})$ to industrial wastewater samples $(100 \mathrm{~mL})$

\begin{tabular}{|c|c|c|}
\hline \multicolumn{2}{|c|}{ Gold species, } & Recovery, \%* \\
\hline & & \\
Gold (III) added, $\mu \mathrm{g}$ & Gold (III) found, $\mu \mathrm{g}$ & \\
& & \\
\hline 0.0 & 0.0 & 0.0 \\
5.0, & $4.9 \pm 0.12$ & $98 . \pm 2.42$. \\
8.0 & $8.2 \pm 0.22$ & $5.0 \pm 2.7$ \\
10.0 & $10.3 \pm 0.32$ & $103.0 \pm 3.2$ \\
\hline
\end{tabular}

*Average $(\mathrm{n}=5) \pm$ relative standard déviation. 


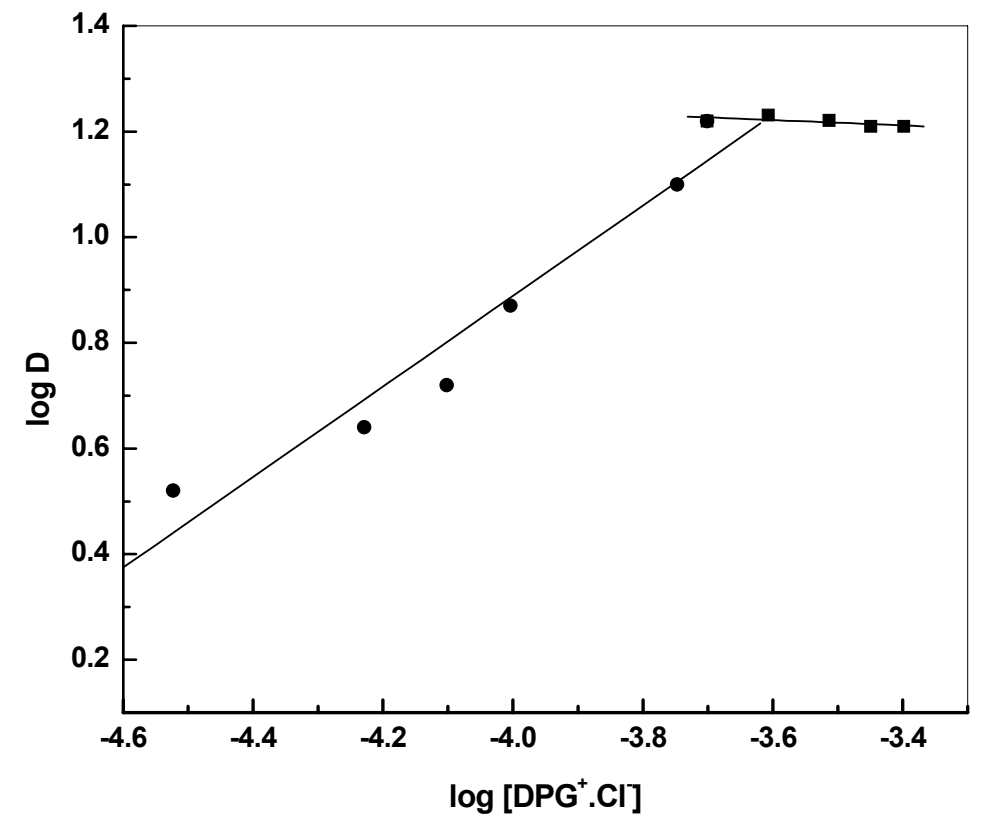

Figure 1. Plot of $\log \left[\mathrm{DPG}^{+} . \mathrm{Cl}^{-}\right]$versus $\log \mathrm{D}_{\mathrm{Au}}$ of the ion associate $\left[\mathrm{DPG}^{+} \mathrm{AuCl}_{4}^{-}\right]$Conditions: Aqueous phase $(20 \mathrm{~mL})$ at $\mathrm{pH} 6-7$, organic solvent $=5 \mathrm{~mL}$ and $\left[\mathrm{HAuCl}_{4}\right]=6.2 \times 10^{-6} \mathrm{~mol} \mathrm{~L}^{-1}$ 